\begin{abstract}
Anna Kubiak
University of Lodz, Faculty of Economics and Sociology

Department of Social Research Methods and Techniques

e-mail: anna1.kubiak@neostrada.pl
\end{abstract}

\title{
Lobbying in Polish law and practice*
}

\begin{abstract}
This article presents both the legal regulations concerning lobbying in Poland and an evaluation of lobbying practices. It refers to the results of the sociological research conducted among the members of the Polish Parliament, professional lobbyists and journalists who cover parliamentary issues. The research was conducted in cooperation with the Stefan Batory Foundation's Anti-Corruption Programme from May to July 2008.
\end{abstract}

Keywords: formal lobbying, informal lobbying, Act on Lobbying Activities, enactment of legislation

JEL Classification: D72, D73, K41

\section{Lobbying — characteristics of the concept}

Lobbying is a fuzzy concept as well as a complex, diverse and variously assessed phenomenon. The word lobbying itself means actions undertaken in a place called lobby. In the British House of Commons and other parliaments, it is the entrance hall or the room available to the public which can be used for contacts between deputies and non-members of the parliament. The Oxford Dictionary (1989,

\footnotetext{
* The article is an updated version of the paper published in Polish in the Annales. Ethics in Economic Life, 16, 131-144
} 
p. 1074) records the first example of the use of the word "lobby" in this sense in 1640. In the American tradition, a lobby is associated with the Congress building. In America, lobbying emerged two hundred years later than in England, but it is the USA that is considered a country where lobbying has developed most fully and where very diverse forms and variants of lobbying have been created (Wiszowaty, 2010, p. 148). There, a lobby means not only a corridor in the parliament building but every "entrance hall" where casual meetings of politicians with businessmen, journalists or spokespersons representing group interests, primarily interests of industrialists, can take place. The English understanding of lobbying as a practice closely related to the activities of the parliament has been expanded in the United States to also include activities directed at the executive branch. In the Anglo-Saxon tradition, this type of practice has gained the name "behind-the-scene diplomacy."

Historically, the phenomenon of looking after the interests of various groups and circles dates even further back - to the organisation of social relations by the state. Since ancient Greece, citizens and their various organisations, later court camarillas, informal groups based on the client-patron relations have sought to influence political and legislative decisions (Jasiecki, Molęda-Zdziech \& Kurczewska, 2006, p. 13). Nowadays the connotation of this concept has expanded, gaining new meanings and content. It encompasses all activities affecting decisions of various centres of power. Thus, the circle of people and institutions engaging in lobbying has expanded, along with a set of problems associated with lobbying occurring at various levels: from the supranational level to the state, local government, corporate, non-governmental and media level.

However, there is no universally accepted definition of lobbying. In the classic definition of Philip Kotler, lobbying is defined as contacting and persuading members of legislative bodies and public officials to adopt specific legal and administrative solutions (1994, p. 621). Lobbying is also treated as a kind of instrument for formulating and conveying arguments to decision-makers-it is important therefore to establish direct, personal contacts between individuals or lobby groups and representatives of the power apparatus. Thus, mutual communication on the political, economic or social level gains importance. Such relationships can appear in various interpersonal contexts: between individuals, groups or organisations. One of the most important aspects of lobbying is "persuading, providing and obtaining information in order to promote specific decisions" (Jasiecki, Molęda-Zdziech \& Kurczewska, 2006, p. 18). Lobbying is sometimes compared to other forms of exerting pressure, such as public relations or marketing (there is even a definition of lobbying as the marketing of ideas), but its specificity lies in the fact that the target audience consists primarily of decisionmakers representing the public sphere and interests at various levels. What is also characteristic of lobbying is the presence of an intermediary - a lobbyist - who is a link in the process of communication between citizens or interest groups and various types of institutions making decisions in their matters. The literature distinguishes several areas of lobbying activities (Jasiecki, Molęda-Zdziech \& Kurczewska, 2006, p. 58): 
(1) a lobbyist makes efforts to influence various government decisions concerning e.g.: awarding grants, entering into contracts, appointments to various positions, development of strategies;

(2) a lobbyist is a full-time employee of a private enterprise in the department responsible for contacts with the government;

(3) a lobbyist works for groups established to deal with and support one issue;

(4) a lobbyist is employed in third sector organisations;

(5) a lobbyist is employed in companies that run advertising campaigns in various mass media;

(6) a lobbyist is employed in companies engaged in lobbying the government and the parliament.

A lobbyist usually represents various interest groups, i.e. different types of organised associations, with specific goals. Their creation is the effect and expression of the ability and readiness of citizens to organise themselves independently and influence legislation, institutions of power and public opinion (Marshall, 2005 , p. 108). Sometimes the term "organised interests" is used instead of the term "interest group" to emphasise that the membership is not always clearly formalised. The terms "pressure group", "impact group", "organised interests", and "stakeholders" are often used interchangeably (Kurczewska, 2011, p. 19).

In modern systems of representative democracy, two models of lobbying are usually distinguished: "pluralistic", referring mainly to Anglo-Saxon countries, primarily to the United States, and "corporatist", characteristic of Western European countries. In the US model, lobbying and pressure groups are treated as a normal, natural manifestation of democratic life, and organised defence of interests is an element of participatory democracy. In this model, it is recognised that political institutions, such as the parliament or political parties, are not enough to satisfy the needs of the sovereign - the nation, hence it is necessary for there to be other intermediaries between citizens and elected government officials. In the "corporatist" model, basic decisions, in the sphere of economics as well as politics or culture, are made because of arrangements between the state and various organisations, associations or unions, and therefore politics is based on negotiations between groups, often associated in the form of corporations, not only business ones but also professional or environmental ones, and the government.

In the "pluralistic" model, a change in lobbying practices has been postulated and partially implemented. Until the beginning of the $20^{\text {th }}$ century, lobbying activities were dominated by corrupt practices such as bribes and blackmail, nowadays, because of the enactment of several legal acts, efforts are being made - with varying effectiveness - to limit such practices. More "civilised" forms of lobbying are being introduced in which the provision of information and the use of various types of persuasion are prevalent. Nowadays, in the "pluralist" American model, three models of lobbying can be distinguished: 
(1) parliamentary-lobbyists contact senators and representatives of the Congress seeking to convince them to their way of thinking;

(2) technical - a lobbyist is perceived as an expert in a given field whose task is to provide specialist knowledge that is needed to understand the consequences of adopting specific legal solutions;

(3) procedural - related to the operations of the administration when each new project must undergo evaluation by the public.

Lobbyists dealing with procedural lobbying prepare opinions and information on behalf of groups of people or interest groups which these projects may concern. It is believed that it is through lobbyists that organised groups of citizens participate in public life, which in turn facilitates obtaining support for state-run policies. It is recognised, therefore, that at least some lobbying activities contribute to the democratisation of social life.

In the European tradition, it is difficult to speak of one model of lobbying. Above all, there is more scepticism concerning lobbying activities, as lobbying is mainly associated with the pursuit of vested interests, sometimes at the expense of public interest, in a way that often raises both legal and ethical concerns. Decisions in countries using elements of the corporatist system are a result of negotiations and bargaining in which political and lobbying institutions, as well as various professional and industrial corporations, participate, but the decision process on both sides is more centralised (Kubiak \& Krzewińska, 2010, pp. 420-421).

Regardless of tradition in the approach to lobbying, in various countries its positive as well as negative aspects are pointed out. Among the positive ones, the following can be mentioned:

(1) filling the gap between the individual and the state, thus creating premises for the development of civil society;

(2) drawing attention to significant problems and new emerging challenges;

(3) enforcing access to public information;

(4) providing a chance to balance the positions of various groups, including the enhancement of the status of weaker groups;

(5) creating a plane for contacts between citizens and elites;

(6) pragmatising discourse over political or ideological divisions.

Among the negative features of lobbying, the following can be indicated:

(1) contributing to the erosion of the democratic order - the freedom of presenting interests may favour the strongest impact groups at the expense of other, weaker, less organised and poorer groups. Oligarchisation resulting from their strength may lead to the imposition of their interests, contrary to the common good;

(2) uncontrolled or unsuccessfully controlled lobbying can lead to the pathologisation of social life through the corruption of representatives of authorities by lobbyists;

(3) in weaker, less organised states, there is a danger of making state interests dependent on strong international pressure groups operating to promote the interests of strong global corporations or foreign investors. 


\section{Lobbying-formal and legal solutions}

Lobbying activities are regulated in various ways in individual countries and at the level of the European Union. A detailed discussion of these issues can be found in the literature (Jasiecki, Molenda-Zdziech \& Kurczewska, 2006, pp. 77-102). These regulations have a twofold character: legal and ethical. The legal dimension is associated with the introduction of detailed rules, sometimes statutory. Such solutions have been introduced in the USA, Canada, Australia, Germany, the European Union, as well as in Poland. The ethical dimension of lobbying focuses on the issue of self-regulation, i.e. the analysis to what extent a given group implements various measures to regulate and standardise its activities. This applies to both groups and people performing public functions as well as various corporations and organisations engaging in lobbying in a variety of forms. The ethical dimension of lobbying is as important as statutory solutions, since not all activities, especially in the public sphere, can be regulated in accordance with the law. Ethical behaviour - decency in actions - is an asset whose importance cannot be stressed enough, and which is difficult to substitute.

In Poland, the Act on Lobbying Activities limited to the law-making process was adopted in 2005. Previously, there were regulations in Polish law focusing on the targets of lobbyists, i.e. persons occupying various public positions. There were, therefore, ethical codes for various groups, ethics committees for parliamentarians, rules for the operation of individual offices, and supervisory institutions. Partially, those issues were regulated by the Act on Exercising the Mandate of Deputy and Senator (Journal of Laws of 1996, No. 73, Item 350), the Act on Limitation on Conducting Business Activity by Persons Performing Public Functions - the so-called Anti-corruption Law (Journal of Laws of 1997, No. 106, Item 679) or the Civil Service Act (Journal of Laws of 1999, No. 49, Item 483). In the 1990s, in the face of a growing list of negative examples of inappropriate and often pathological relations between the sphere of politics and economy accompanied by a high level of corruption (cf. Kubiak, 2003), demands were made to introduce legal regulations directly concerning lobbying. After several years of discussions among politicians, experts and representatives of various circles, following unfinished legislative attempts, the scope of the 2005 Act in its final version was limited to legislation at the level of central institutions. The Act, consisting of 24 articles, defines the principles of transparency of lobbying activities in the legislative process, rules for the performance of professional lobbying activities, forms of supervision over these activities as well as rules governing keeping a register of entities engaged in professional lobbying activities. Pursuant to the Act, lobbying activities comprise any activities carried out by legally permitted methods aimed at influencing public authorities in the law-making process, and professional lobbying activities comprise paid lobbying activities conducted for third parties to have the interests of these parties considered. The Act also imposed on the Council of Ministers the obligation to publish in the Public Information Bulletin plans for the enactment of regulations and all documents related to works 
on draft laws and regulations. The Act also introduced a new institution of a public hearing into Polish law, which allows various entities to participate in law-making. The chairmen of the parliamentary clubs and groups, as well as the ministers, have been obliged to provide information regarding the employees of the deputies' and senators' offices as well as employees working in the ministries' political offices.

As in the case of many Polish legal acts, the Act on Lobbying Activities immediately after its adoption was treated as a "trial act", a pilot act which, after evaluating its functioning, may be subject to amendment. Most experts assessed it very critically (Wiszowaty, 2006, pp. 47-54). It was even considered a "defective law", "an act prepared in a hurry, without the necessary analyses, and ill-adapted to the real needs of Polish public life" (Zbieranek, 2010, p. 142).

\section{Perception of lobbying and lobbying activities}

The perception of lobbying and lobbying activities, also in the light of the provisions of the Act on Lobbying Activities, was the subject of research carried out under my direction at the request of the Anti-Corruption Programme of the Stefan Batory Foundation in 2008, at a time when it was possible to assess the functioning of the law in practice. ${ }^{1}$ The research focused on lobbying in the law-making process. This phenomenon was thus narrowed down to various relations with and influences directed at the lawmakers in the parliament. The study covered a quarter of the randomly drawn - in proportion to the number of seatsparliamentarians (115 deputies and 25 senators) to which an anonymous survey was addressed. Interviews were also held with journalists working as parliamentary reporters who had previously participated in discussions on lobbying in the Stefan Batory Foundation and agreed to participate in the research (15 free interviews were conducted regarding their professional biography, contacts with lobbyists, assessment of lobbying in Poland, definition and perception of lobbying and the lobbying pathologies that they had observed or heard about). The respondents with the most extensive knowledge concerning the impact of lobbying on the lawmaking process were the lobbyists registered in accordance with the Act on Lobbying Activities in the Sejm, Senate and Ministry of the Interior, carrying out various activities: business or promotional consultancy, legal and expert services provision, and image creation. Twelve in-depth free interviews were conducted with the lobbyists about their work-related experiences, their opinions about overt and hidden lobbying in Poland, the restrictions placed on lobbyists and the opportunities provided by the Act on Lobbying Activities, and development prospects of this type of activity in Poland.

\footnotetext{
${ }^{1}$ A detailed description of the research and its results is presented by Kubiak (2008, pp. 63-163).
} 
Lobbying in its popular understanding is perceived as a negative phenomenon, corruption-related, even pathological. It was interesting to check how lobbying was defined by people interested in it professionally in various ways.

The parliamentarians were asked to provide their own definition of lobbying (in response to an open question: what is lobbying and what is lobbying associated with?) along with the assessment of 18 statements describing lobbying in various ways. Most of the parliamentarians presented their own suggestions for understanding lobbying (79\%), but $21 \%$ did not write anything on the subject. The terms which I called positive-neutral (50\% of all the responses) dominated, presenting lobbying as a form of influence of some entities (individuals, groups, institutions) on others. They said, for example, that lobbying "is a professional activity consisting in influencing the shape of law in the interest of specific groups, exerting pressure on decisions of public authorities in order to obtain a favourable decision", "actions of interest groups directed at government bodies in order to obtain desired decisions, consisting in the provision of reliable information and education", "professional, transparent activity of professional intermediaries between interest groups and centres of administrative and political power", "actions aimed at obtaining support for a specific solution, addressed to the power-wielding entities, politicians", "one of the ways of presenting their arguments", "influencing deputies and councillors through social and economic organisations and groups of citizens in order for the Sejm and municipal councils to adopt solutions promoted by these groups".

Providing their own proposals for the definition of lobbying, nearly $1 / 5$ (17\%) of the parliamentarians drew attention to both positive and negative features of lobbying, pointing to their ambivalent stance towards this matter. Here are some examples of answers provided: "in the positive sense, it is associated with activities of specialised groups or people aimed at presenting arguments and positions (of entities represented) in the law-making process; in the negative sense, it is associated with influencing decision-makers in order to obtain decisions beneficial for a given group or entity in an informal manner, often supported by nonsubstantive arguments"; "influencing decisions in a formal and informal manner in the interest of the group that the lobbying person represents"; "two definitions of lobbying function in political life: (1) as a professional, transparent activity, presenting arguments of various professional and social groups, promoting their solutions, (2) as dysfunctional lobbying activities aimed at politicians in order to satisfy one's own selfish interests"; "in Poland lobbying is associated with making suspicious business deals, but it does not have to be that way".

In addition to positive-neutral and ambivalent statements, $12 \%$ of the parliamentarians surveyed assessed lobbying negatively, for example: "lobbying is a system of cliques (cronies) or family connections aimed at unfairly achieving financial benefits and satisfying one's own desires, which in turn inevitably leads to camouflaged corruption, and consequently to economic and moral losses and crimes", "it is a mediation between certain not entirely transparent deals. I associate lobbying with acting as an intermediary in such business deals between two 
entities."; "in Poland, lobbying is associated with a form of pressure, often supported by financial means, so it has a rather negative connotation"; "unfair influence exerted by business on politics".

Apart from the spontaneously formulated definitions, the surveyed parliamentarians also presented their position by accepting ("I agree strongly" and "I quite agree") or rejecting ("I rather disagree" and "I strongly disagree") 18 statements defining lobbying in various ways. The most commonly accepted statements were the statements of a neutral-descriptive nature (in brackets the percentage of responses expressing the acceptance of a given statement):

(1) Lobbying is a professional activity of professional intermediaries between interest groups and centres of administrative or political power $(83 \%)$.

(2) Lobbying allows large corporations to legally pursue their interests (80\%).

(3) Lobbying is an activity that makes politicians better informed about a given matter $(75 \%)$.

(4) Lobbying facilitates access to politicians $(71 \%)$.

(5) Lobbying civilises “a vicious fight for one's own interests" (68\%).

(6) Lobbying means exerting pressure on politicians to obtain favourable statutory solutions $(66 \%)$.

The most frequently rejected statements are the statements directly related to politicians:

(1) Lobbying blocks ordinary people's access to politicians (79\%).

(2) Lobbying is an activity aimed at buying the vote of a given politician $(70 \%)$.

(3) Lobbying is the "fifth power" (64\%).

(4) Lobbying leads to abuse of power and obtaining only private benefits $(63 \%)$.

(5) Lobbying means selling influences (62\%).

The responses provided by the journalists were dominated by a rather positive image of lobbying, as they most often referred to it as an overt influence exerted on people who make decisions in the institutions of power. In their opinion, lobbyists provide the deputies with information, convince decision-makers with their arguments, and "fight" for support of their own solution. Persons professionally engaged in lobbying monitor legislative work on an on-going basis, sometimes detecting inappropriate solutions. The journalists also pointed to "the other side" of lobbying - informal, hidden activities that result in great "scandals" (Rywin or Dochnal scandal), which cements the negative image of lobbying and hinders the development of legal, professional lobbying. Although the professional lobbyists registered in the Sejm (32 professional lobbyists were registered in 2012) or the Ministry of Administration (227 lobbyists or institutions of professional lobbyists were registered) decidedly opposed associating professional lobbying with its common, scandal-related definition, they were also aware of the negative atmosphere around lobbying. Defending the good name of professional lobbyists, they emphasised the important role of lobbying in the law-making pro- 
cess - mainly providing decision-makers with information and knowledge as well as analysing decision-making processes, thus fostering their transparency and enforcing access to public information. Based on the material derived from the free interviews conducted, several types of lobbying can be distinguished. ${ }^{2}$ On the basis of the journalists' statements, the following types of lobbying can be indicated: "political" lobbying - when politicians through individual and party contacts attempt to influence legislative decisions (hence many entrepreneurs wish to employ former politicians because they know that they will "have a clout" with current politicians) and "journalist" lobbying-when journalists play the role of secret and informal lobbyists, writing to order or "to please the sponsor".

Sometimes, officials serving in the parliamentary committees and subcommittees or officials from the various ministries act as lobbyists - this kind of lobbying was described as "legislative". "Tactical" lobbying is used in these cases when lobbyists have developed a strategy of "disseminating" some information using the most modest means - they know which politician to turn to so that he or she can effectively "pass" on messages that they convey. Official lobbying can be done not only by professional companies that carry out the instructions entrusted to them but also by associations, professional organisations and trade unions that lobby for specific provisions in legal acts - this type of lobbying was defined as "lobbying by organisations". Journalists also mentioned lobbying which can be described as "unidentified"-when it is not known who takes part in committee or subcommittee meetings, who is a consultant, and who advises the parliamentarians, this is an obvious example of hidden lobbying. The journalists also provided examples of lobbying which could be described as "parliamentarian" lobbyingwhen the deputies promote a solution because it will benefit particular people, usually someone from their family, their friends or close acquaintances (e.g.: lobbying for specific solutions regarding biofuels, reflective vests, or hands-free car phone systems).

The professional lobbyists surveyed mentioned completely different types of lobbying such as:

(1) passive (receptive) lobbying - used when the government holds consultations with an interest group, i.e. the initiative comes from the lawmakers;

(2) active lobbying - used when a group lobbies for a specific solution; the initiative remains on the side of those who will benefit from the solution;

(3) "soft" lobbying - used when a lobbyist creates the right atmosphere around a given problem or phenomenon but does not encourage the adoption of a specific solution;

(4) substantive lobbying - related to the preparation of arguments and making legislators aware of a given issue by using these arguments in persuasive actions.

Common in the statements of both the journalists and professional lobbyists is the distinction of overt lobbying, also referred to as permitted or transparent lobbying. It is practised by people who openly act as advocates of someone's

\footnotetext{
${ }^{2}$ Various other types of lobbying, e.g.: professional lobbying, "ad hoc" lobbying", "wild" lobbying,
} also known as "guerrilla" or "cowboy" lobbying, are described by Jasiecki (2000, pp. 35-67). 
interests. Their main tasks include monitoring the course of legislative processes and, at the right moment, presenting arguments that would convince decision makers to adopt solutions favourable for their clients. The existence of many such entities which present different points of view in a given matter allows a consensus to be reached and, as a result, a good law to be written. Hidden lobbying is its opposite - the process of influencing lawmaking is secret in the sense that the person who exerts pressure does not act openly as a lobbyist. Such a person often "hides" because, formally, he or she officially acts as a journalist, expert, adviser, parliamentary assistant or employee who works for the parliament. The conduct of such "crypto-lobbyists" does not violate criminal law, as they do not use corruption or lies - they act like open lobbyists do but in a different capacity.

Unacceptable lobbying may be conducted by both open and hidden lobbyists - it is a matter of the type of action taken: inviting for trips, lending expensive items (a laptop for a deputy), or seeking private contacts with a parliamentarian. And finally, there is illegal lobbying - breaking the law, characterised by corrupt activities.

Hidden and unacceptable lobbying is not only contrary to decency but also illegal. The parliamentarians rarely admit that they have encountered hidden, unofficial lobbying. These forms of lobbying, as indicated, are most commonly used by:

(1) trade unions- $16 \%$,

(2) local government authorities-19\%,

(3) social and non-governmental organisations- $15 \%$,

(4) sectoral associations, sectoral interest groups-13\%.

Most of the parliamentarians surveyed declared that they had never encountered any instances of unofficial, hidden lobbying by any of the above-mentioned entities and that they had also rarely encountered lobbying by "classic" entities lobbying in the economic field, such as law firms, companies providing consulting and advisory services or business associations. The parliamentarians are subjected to various pressures, their favour is sought, and they are asked for interventions. It can even be said that this is an integral part of their social role. As they pointed out, they had been asked, for example, for help in finding a job (as declared by $42 \%$ of the respondents) and for assistance in dealing with specific matters important for residents of their district or matters important for a given town (50\%). Repeated requests in the form of informal lobbying were indicated even much less often - only $3 \%$ of the respondents indicated that they had been repeatedly asked to support legislative solutions favourable for some companies or entrepreneurs and $16 \%$ had been asked to support solutions beneficial to some specific professional groups.

As far as the forms of influencing or exerting pressure on the parliamentarians are concerned, they most often encountered the provision of information, sending petitions and letters or extending invitations to participate in the presentations of arguments by various economic and social entities. These are legal or even recommended forms of contact with parliamentarians. In the course of legislative procedures, during the work of parliamentary committees and subcommittees, the respondents most often encountered attempts to influence the content of 
the prepared acts on the part of persons acting as experts (often- $21 \%$, seldom$44 \%$ ), parliamentarians from other parties (often-19\%, seldom-40\%), parliamentarians from their own party (often-15\%, seldom-47\%), persons invited to meetings as guests (often-15\%, seldom-35\%), officially registered lobbyists (often-4\%, seldom-31\%), and persons cooperating with the deputies as assistants and advisors (often-3\%, seldom-16\%). In addition, 10\% of the respondents pointed to other, previously unmentioned persons, for example, officials, company presidents, ministers, representatives of professional corporations, the Church representatives, employees of the Sejm legislative office, foreign parliamentarians, and diplomats from other countries. Choosing from the indicated list of factors conducive to unacceptable lobbying, the parliamentarians pointed out as the most important:

(1) no verification of lists of parliamentary experts $-70 \%$ of responses,

(2) conflict of interest affecting public officials-70\% of responses,

(3) too narrow list of parliamentary experts - $69 \%$ of responses,

(4) conflict of interest arising from experts' professional activities $-57 \%$ of responses,

(5) commissioning expert opinions from people outside the list of official experts- $55 \%$ of responses,

(6) lack of knowledge about occupations and interests of assistants, advisers, and co-workers of the parliamentarians- $54 \%$ of responses.

As remedial measures, improving lawmaking procedures and protection against unacceptable lobbying, the following solutions were most frequently indicated: amendment to/inclusion of more specific provisions in the Act on Lobbying Activities (46\%) and adoption of the Act on Legislation (29\%). Only 6\% of the parliamentarians surveyed indicated a total ban on lobbying.

In the opinions of the parliamentarians, the following organisations were considered as the most effective in their lobbying activities (presented in the order of indications): trade unions - $62 \%$ of responses, local authorities-38\%, sectoral associations, groups of sectoral interests, e.g.: shipyard workers, miners-34\%, international corporations - $32 \%$, business associations-28\%, large domestic enterprises-22\%, law firms-17\%, social and non-governmental organisations$17 \%$, companies providing consulting and advisory services- $15 \%$, professional corporations $-14 \%$, the Church-12\%, and managers of state-owned companies- $8 \%$ (percentages do not add up to 100, as three answers could be selected). On the other hand, according to the respondents, the most effective among the groups of lobbying people are: people who act as experts- $57 \%$ of responses, guests invited to participate in the work of committees and subcommittees-32\%, journalists $-29 \%$, officially registered lobbyists $-27 \%$, other parliamentarians from their own party-21\%, parliamentarians from other parties - $9 \%$, and people cooperating with the parliamentarians, e.g.: their assistants, advisers-8\% (percentages do not add up to 100, as two answers could be indicated). The parliamentarians, unlike the journalists and professional lobbyists, are quite positive in their assessment of the Act on Lobbying Activities (it is worth noting, however, that the majority of them adopted the law). Most of the parliamentarians believe that the 
Act: established a clear, transparent framework of contacts between lobbyists and the parliamentarians (60\%), created opportunities to present one's own interests to various groups and institutions $(77 \%)$, and made law-making more transparent at the Sejm (59\%) and government level (53\%). However, the minority (48\%) of the surveyed parliamentarians believe that the Act limited unacceptable, illegal lobbying and that is also reduced (45\%) the ability of groups or institutions without the proper organisational structure and adequate financial resources to exert influence.

This "trial", the i.e., the pilot act, is much less positively assessed by the professional lobbyists and journalists participating in the survey. They draw attention to a few of its significant flaws. The provisions of the Act can be easily bypassed. This is due, among others, to the narrow definition provided for in the Act-legal lobbying can only be carried out for third parties. In practice, this means that people acting for their own organisation or association are not lobbyists pursuant to the Act and they can engage in actual lobbying activities without entering the register of lobbyists. Also, external experts invited by various organisationscompanies or associations of entrepreneurs - can freely lobby for them. This is also confirmed by the journalists surveyed - part of lobbying activities might have gone "underground". The narrow definition of lobbying in the Act means its limitation to the legislative process, and thus the actions and procedures carried out in the parliament. Meanwhile, a lot of lobbying activities take place in other institutions, including the ministries, whose procedures and actions are not covered by the law. Moreover, these procedures are not uniform, although individual ministries introduce their own solutions, for example, monitoring meetings with lobbyists and registering these meetings, including also meetings with stakeholders who formally do not have the status of lobbyists. These are actions implemented as part of the anti-corruption strategy. As a result, most lobbying companies and lobbyists do not register, especially since professional lobbyists are obligated to wear special badges in the parliament. In the face of a negative image of lobbying, this fact hampers the work of official and registered lobbyists - it can even be said that they are "marked". As noted during monitoring the law-making process, the number of people participating in these proceedings in no way corresponds to the number of people who, pursuant to the Act, have submitted the information that they wish to participate in the work of a given committee. Also, a very important procedure introduced by the provisions of the Act on Lobbying Activities, i.e. a public hearing (which provides the opportunity for all interested parties to present their arguments, including - which is very important-organisations and groups of citizens considered as weaker, for example, financially), is used very rarely and with great difficulties (see Przejrzystość procesu stanowienia prawa, 2008, p. 46).

On the plus side of the law, it should be noted that it has sorted out the "lobbying element", hampered ad hoc lobbying, enforced the professionalisation of lobbying companies in Poland, and made many decision-makers aware of the importance of lobbying in the legislative process. 
The research discussed here briefly aimed at presenting the issue of lobbying as an important instrument of social communication, information exchange and law enactment, as well as its functioning in Polish practice. As it can be seen, a great deal remains to be done in this area, and the Act on Lobbying Activities of 2005 remains a "pilot" law that has yet to be amended.

\section{References}

Jasiecki, K. (2000). Lobbing gospodarczy w Polsce. Studia Socjologiczne 4, 35-67.

Jasiecki, K., Molęda-Zdziech, M., \& Kurczewska, U. (2006). Lobbing. Sztuka skutecznego wywierania wptywu. Kraków: Oficyna Ekonomiczna.

Kotler, Ph. (1994). Marketing. Analiza, planowanie, wdrażanie i kontrola. Warszawa: Gebethner \& Ska.

Kubiak, A. (2003). Łapownictwo w świadomości potocznej $i$ doświadczeniu Polaków. Łódź: Wydawnictwo Uniwersytetu Łódzkiego.

Kubiak, A. (2008). Ustawa o lobbingu, lobbing i proces stanowienia prawa w oczach parlamentarzystów, lobbystów i dziennikarzy. In Przejrzystość procesu stanowienia prawa. Raport z realizacji projektu "Spoleczny monitoring procesu stanowienia prawa”. Program Przeciw Korupcji (pp. 63-163). Warszawa: Fundacja im. Stefana Batorego.

Kubiak, A. (2013). Lobbing w polskim prawie i praktyce. Annales. Ethics in Economic Life, 16, 131-144.

Kubiak, A., \& Krzewińska, A. (2010). Lobbing jako element infrastruktury społeczeństwa obywatelskiego. In Z. Kurcz \& I. Taranowicz (Eds.), Okolice socjologicznej tożsamości. Księga poświęcona pamięci Wojciecha Sitka. Wrocław: Wydawnictwo Uniwersytetu Wrocławskiego.

Kurczewska, U. (2011). Lobbing i grupy interesu w Unii Europejskiej. Warszawa: Wydawnictwo Naukowe PWN.

Marshall, G. (Ed.) (2005). Stownik socjologii i nauk spotecznych. Warszawa: Wydawnictwo Naukowe PWN.

The Oxford English Dictionary. (1989). Oxford University Press.

Przejrzystość procesu stanowienia prawa. Raport z realizacji projektu "Spoleczny monitoring procesu stanowienia prawa”. Program Przeciw Korupcji (2008). Warszawa: Fundacja im. Stefana Batorego.

Ustawa $z$ dnia 7 lipca 2005r. o działalności lobbingowej $w$ procesie stanowienia prawa (Dz.U. z dnia 6 września 2005) [Act of July 7, 2005 on Lobbying Activities in the Legislative Process (PL)].

Wiszowaty, M. M. (2006). Ustawa o działalności lobbingowej w procesie stanowienia prawa. Przeglad Sejmowy 5, 41-71. 
Wiszowaty, M. M. (2010). Regulacja prawna lobbingu samorzadowego na świecie. In G. Makowski (Ed.), Lobbing w samorzadzie województwa. Raport z badań i monitoringu (pp. 148-175). Warszawa: Instytut Spraw Publicznych.

Zbieranek, J. (2010). Wnioski i rekomendacje. In G. Makowski (Ed.), Lobbing $w$ samorządzie województwa. Raport $z$ badań i monitoringu (pp. 141-147). Warszawa: Instytut Spraw Publicznych. 